\title{
段織に関する研 究*
}

\section{1. まえがき}

近年, 繊維工業は急速な発展を遂げ, 新しい纎維がつ ぎつぎと開発されている. 一方㵶維製品とくに織物む高 品質が要求されてきているが, 最近の労働力不足はこれ を熟練によって達成することを不可能な情況に追込んで いる.

したがって，あらゆる産業がそうであるように，繊維 産業においても, 機械に対する要求が自動化からさらに 一歩進んで高性能化に向かいつつある.ところが一般の 繊維は高分子であって, その物理的性質は種類によって 千差万別である．とのような繊維を対象として，その製 品を機械的に均一化し高品質化することは非常にむずか しい.

とのような問題のうち, 複雑な組織とか特殊織物とい うような分野での問題は多岐にわたり, それぞれ個々の 解決策が必要とされるであろう。

織物織成というプロセスはたて糸とよて糸を交さく させることであるが，その品質に影響する囚子は非常に 多い. 屯っとも一般的な欠点として古くから問題にされ ながら, 現在なお完全な解決が与えられていないのは織 段であろう.

織段は機械段, 止め段および織付け段（きずほぐし 段）に大別されるが，織付け段は製織中に発生した織き ずを, 織布工が発見して織機上でそのきずの発生した 部分のよて糸を抜取り,ふたたび製織を開始すると き，そのクロスフェル付近に発生する段（布面上の横す じ）であって，織布工の技能の巧拙によってその大きさ は異なり，しかあいかにたくみに織り付けてあ決して元 全に除くことはできない.
会員乾昇**

このような人為的な囚子のあのを別に考えれば，機械 的に防ぎ得るものとしては，機械段および止め段の二つ である。

機械段とは布面上に規則的に連続して現われる横縞状 の不均一部分をいう.しかし, 規則的な縞状に認められ る織段のうちでも, 不均一なよて系張力や繊度むらな どのよて関係で生じたものは，見かけは機械段と類似 しているが全然異質のあのである. いわゆる機械段とは 織機の主運動中, 直接たて関係に結びつく送出し, 巻取 り，開口および おさ打ちなどの要素によって生ずるあ のをいい，しかすたて系自体の物理的性質に起枂る ことはほとんどない。

また止め段とはなんらかの原因で織機が停台して, 織 成のプロセスが一時中段し，ふたたび運転が始められる と, その停台および起動の行なわれた布面上の位置に発 生するよこすじである.

これは機械段とは異なり, 織成のプロセスが一時中断 するととによって, クロスフェル近傍における布とた て糸の構成が時間軸に対して定常状態と異なり, 不連続 点を含むととから発生する.

これが系の粘弾性的性質に起因することは明らかであ り, あらゆる種類の糸に対する物理的性質は多くの人び とによって明らかにされている. しかし, その個々の物 理的性質に対してさらに織成というプロセスのクロスフ エル近傍の現象を追㠰しても, 織段を防止する普遍的な 手段を見出すととは非常に困難であろうと考えられる.

筆者はこの機械段之止め段について系の粘弾性的性質 からよりあ,むしろ織機の動特性すなわち機械的な構造 とその運動状態を解決するととから，一般論的または垁 用上許される範囲内での織段防止の手段を見出すととを

* Thick and Thin Areas in Woven Fabrics. (昭利 46 年:度 学会賞受賞論文)

** N. Inui, Member. 
目的として本砸労を行なった.

織段に関連する従来の研究について見ると, たて系張 力に関するもの, クロスフェル近傍の組織やプロセスに 関するミクロ的解析, ならびに織布プロセスの数学的表 現からクロスフェルの位置を取扱ったあのなどがあげら $5 \sim 21)$

れる。

しかし従来の研究には直接織段を取上げているものは ほとんどなく，ましてその防止手段に対しては，止め段 に対する Greenwood らの研究があげられるのみであ る.

織段に関してクロスフェル近傍のミクロ的な解析はも ちろん重要であるが，この結果から織段防止の手段を導 き出すことは, 織機の機構や運動の性格から考えて非常 に困難であると思う。

そこで筆者は観点を変え, 織機の機構とその運動とい う面に関して解析を行ない，とくに薄織物に対してそれ らがどのように織段に影響するかを探究し，その結果か ら織段防止の手段を見出そうとした。

織段防止に対して恝用的に許容される範用内でその効 果を上げる期待がもてるものは，常識的であるがり口ス フェルの移動にもっとも大きく影響する送出し装置のテ ンションローラー系の運動を制御するととであろう。

そのためには, テンション ローラー系の運動とたて 系張力との関連性について, てれらの動特性を解析し, これによって定常運転時におけるクロスフェルの位置の 移動を求めれば, 機械段発生の原因を解明できるであろ う.また止め段に対しては，乙れが織機の起動から定常 状態, および定常状態から停止に至る間の過渡現象に起 因するととは明らかで，乙の閒の動特性を解析すれば, その発生のメカニズムが明らかになるであろう。当然の ことではあるが自由振動系であるテンションローラー 系の運動とたて糸張力との相関関係が, 定常状態に対 して過渡現象区間では異なることから，理論と実験によ ってとの差異を定量的に把握しようと考えた。

これらの結果から具体的な織段防止の手段を閒発する ことを最終の目的として木研究を行なった。

本研究を通じて実験に供した織機ならびに試織対象と した織物はつぎのとおりである。一般的にいって織機は 軽織機であり織物は薄物に属する。

1) 綿用自動織機

阪本式 S O-C 型管替自動織機
扰さ幅 $\quad 112 \mathrm{~cm}$
凷転数 $\quad 168 \mathrm{rpm}$

2) ウォータージェットルーム

遠州ジェットルーム

$$
\begin{array}{ll}
\text { おさ㜚 } & 105 \mathrm{~cm} \\
\text { 回転数 } & 360 \mathrm{rpm}
\end{array}
$$

3 ）綿用自動織機に対する試織布 平織

たて糸：40s 綿糸, 総本数 2530 織上幅 $103 \mathrm{~cm}$ よこ系：40s 綿系, よと密度 14.57 picks $/ \mathrm{cm}$

4) ウォータージェットルームに対する試織布 たて系: $30 \mathrm{~d}$ ナイロン, 総本数 3720 織上幅 $97 \mathrm{~cm}$

よこ糸: $30 \mathrm{~d}$ ナイン

\section{よこ密度 $23.23 \mathrm{picks} / \mathrm{cm}$}

\section{2. 織段に関する たて糸張力の解析}

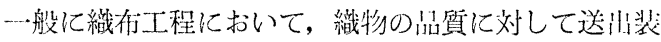
筫の山める比重は非常に大きい. 上くに溥織物の製織に 当たのてその间品質化をはばむ織段に対し，送出装置の

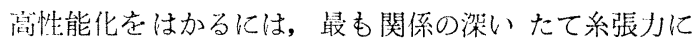
ついてその特性を把握することが先決であると洘え，送 出運動によるたて糸張力の理論的解析を試みた。

まずたて糸張力を動的に取扱って, 定常運転中のた て糸張力を織機のクランク軸 1 回転の全区閒にわたって 解析した。

機械段は定常運転時のクランク 1 回転中の張力变動に よって生ずるのではなく，その変動のしかたが異なった り, 急激にクランク 1 回転中の平均張力が変化した場合 に発生するものである. 後者については送出量や癸取量 の急激な変化が起こらない限り発生しないと考えてよ い. 前者については, クランク 1 回転中のたて糸張力 の変動が大きいとつぎのクランク 1 回転間に対する張力 変化のパターンを変化させる要因となりやすいので, こ のような観点からクランク 1 回転の間におけるたて糸 張力の变化を小さくする方法について, 上記の解析結果 をむとにして考究した，…方止め段に関しては，起動お よび停止時のたて系張力の变化のしかたを定常運転中 のそれと一致させる手段について研究した。

また，得られた解析式が実際と一致するかどうかを碓 かめるため, 実際の織機について数值計算を行ない, こ れを実測した各值と比較検討した.

\section{1 解析方法}

たて系执よび布を一種のば权とみなし，とれらが送 
出し, 巻取り, おさ打ちならびに開口運動によって動 的変位を与えられ，この結果テンションローラーにも 動的変位が与えられると考えて, 第 1 図および第 2 図に 示したモデルを仮定した. 解析を簡単にするため, たて 糸の質量を然視し，たて糸の運動に関連する装置各部の 摩擦抵抗はすべてテンションローラーアーム軸に集中 しているものとした.

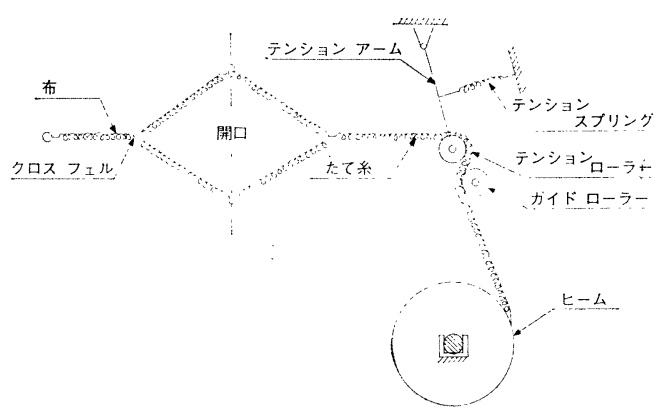

（第 1 図）送出装置のモデル

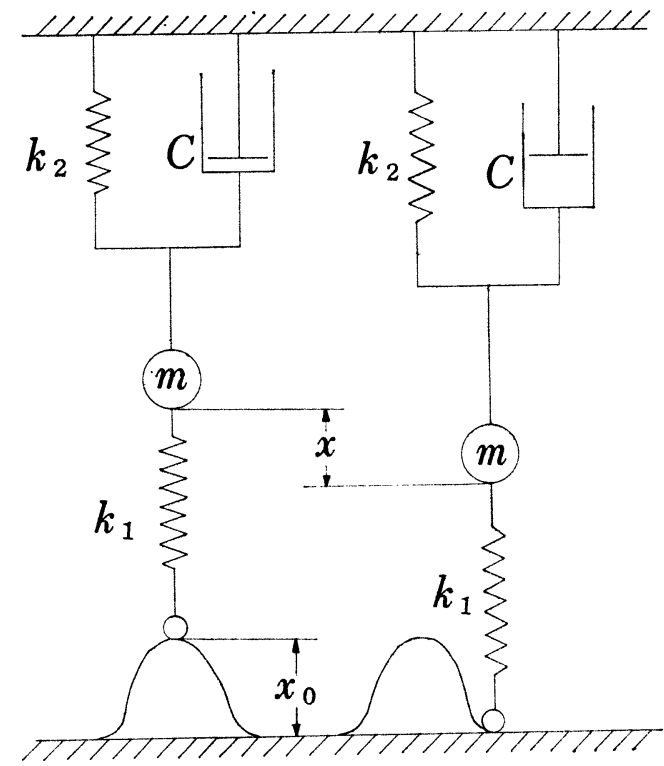

（第 2 図）送出し装置を振動系に置換えたモデル

第 1 図に示す送出装置の張力付与機構のモデルは, 近 似的に第 2 図に示すような振動系のモデルに置き換える ことができるすすなわち，第 2 図において就テンショ ンローラー系の等価質量で, テンション スプリングの ばね定数 $k_{2}$ と等しいばね定数を有するばねを介して 固定壁に取付けられている。一方たて系と布の合成ば ね定数 $k_{1}$ と等しいばねを介して, 送出し, 巻取り, おさ打ちおよび開口の各運動によってたて糸長に与え られる変量と等しい变量を与える力ムによって, 質量 $m$
は押し上げられる.またこの振動采には摩擦力が作用し ているが, 軸受と軸の䦐には薄い油膜が存在するので, この摩擦力は相対速度に比例するとして取扱った.

すなわち本解析では,テンションローラー系を粘性減 衰振動系の力による強制振動系として取扱い, とくに最 大開口時の静止角区間では過渡振動系として取扱った.

このような振動系により動的なテンションローラー の変位 $x$ によるたて系長の変量を求め, てれと送出し, 巻取り, おさ打ちおよび開口運動によるたて系長の変 量 $x_{0}$ との差に糸の ばね定数を乗じたすのをたて系張 力の变量とし, 基準張力に変量を加えてたて糸張力と した。な敃第 2 図および解析式に用いた記号はつぎのと おりである。

$x_{0}$ : 送出し, 巻取り, おさ打ちおよび開口運動によ るたて糸長の変量

$k_{1}:$ 布とたて系との合成ばね定数

$k_{2}$ : テンション スプリングの ばね定数

$k$ : 布とたて系とテンション スプリングとの合成 ばね定数

$m:$ テンションローラー系の等価質量

$c:$ 粘性減衰係数

いま, 送出し, 巻取り, おさ打ちおよび開口による周 期的外力 $P_{1}, P_{2}, P_{3}$, および $P_{4}$ がテンション ロー ラーに作用する場合を考えるとその運動方程式は

$$
m \ddot{x}+c \dot{x}+k x=P_{1}+P_{2}+P_{3}+P_{4} \text {. }
$$
となる。

（1）式の一般解は自由振動の場合の解之, 周期的外 力 $P_{1}+P_{2}+P_{3}+P_{4}$ に対する特解との和として求める ことができる. しかし織段がとくに問題にされる薄織物 について考えれば，おさ打ち力は開口による外力よりは るかに小さく，また送出しならびに巻取運動によるた て糸長の变量が たて系張力の変化に及ぼす影響はきわ めて小さい.

また奏験上，送出し，巻取りならびによこ入れ運動 を取除きおさ打ちならびに開口運動のみを行なわせた ときと, 定常運転時すなわち製織時とのたて系張力差 はほとんど見られなかった。このため（1）式に打ける $P_{1} \sim P_{3}$ を無視して織段に影響する各因子を見出すため の簡単なたて糸張力式を求めることにした。

したがって（1）式において, $P_{1}+P_{2}+P_{3}=0$,

$$
\begin{aligned}
P_{4}= & \frac{B}{2}(\cos \omega t-1) \text { とすれば } \\
& m \ddot{x}+c \dot{x}+k x=\frac{B}{2}(\cos \omega t-1)
\end{aligned}
$$


ただし $B=k_{1} \frac{a+b}{2 a b}\left(\frac{h}{2}\right)^{2}, \omega t=\frac{2 \pi \theta_{1}}{\theta_{2}}$

$a$ : そうこう一致時期におけるクロスフェルからヘル ドまでの距離

$b$ : そうこう一致時期におけるへルドからドロッパー までの距離

$h:$ ヘルドの上下運動の行程

$\theta_{1}$ : たて系が最上位より移動しはじめてから任意時刻 に至るまでのクランク回転角

$\theta_{2}:$ たて糸が最上位より最下位への運動を完了する間

のクランク回転角

$0<t<\frac{2 \pi}{\omega}$ - に対するテンション ローラーの変位を $x_{1}$ とすると, (2) 式より

$$
\begin{aligned}
x_{1}(t) & =-\frac{B}{2 k}\left\{1-\frac{1}{\sqrt{1-\zeta^{2}}} e^{-\zeta \omega_{0} t} \cos (q t-\right. \\
& \left.\tan ^{-1} \frac{\zeta}{\sqrt{1-\zeta^{2}}}\right\}+\frac{B}{2 k \sqrt{\left(1-\lambda^{2}\right)^{2}+(2 \zeta \lambda)^{2}}} \\
& \left\{\cos (\omega t-\delta)-\frac{1}{\sqrt{1-\zeta^{2}}} e^{-\zeta \omega_{0} t} \cos \left(q t-\tan ^{-1}\right.\right. \\
& \left.\left.\frac{\zeta}{\sqrt{1-\zeta^{2}}} \cdot \frac{1+\lambda^{2}}{1-\lambda^{2}}\right)\right\} \cdots \cdots \cdots \cdots \cdots \cdots \cdots \cdots \cdots(3)
\end{aligned}
$$

$t>\frac{2 \pi}{\omega}$ に対する変位を $x_{2}$ とすると

$$
\begin{aligned}
x_{2}(t) & =\frac{B}{2 k} \cdot \frac{1}{\sqrt{1-\zeta^{2}}}\left[e ^ { - \zeta \omega _ { 0 } t } \operatorname { c o s } \left(q t-\tan ^{-1}\right.\right. \\
& \left.\frac{\zeta}{\sqrt{1-\zeta^{2}}}\right)-e^{-\zeta \omega_{0}\left(t-\frac{2 \pi}{\omega}\right)} \cos \left\{q\left(t-\frac{2 \pi}{\omega}\right)-\right. \\
& \left.\left.\tan ^{-1} \frac{\zeta}{\sqrt{1-\zeta^{2}}}\right\}\right]-\frac{B}{2 k \sqrt{\left(1-\lambda^{2}\right)^{2}+(2 \zeta \lambda)^{2}}} \\
& \frac{1}{\sqrt{1-\zeta^{2}}}\left[e ^ { - \zeta \omega _ { 0 } t } \operatorname { c o s } \left(q t-\tan ^{-1} \frac{\zeta}{\sqrt{1-\zeta^{2}}} \cdot\right.\right. \\
& \left.\frac{1+\lambda^{2}}{1-\lambda^{2}}\right)-e^{-\zeta \omega_{0}\left(t-\frac{2 \pi}{\omega}\right)} \cos \left\{q\left(t-\frac{2 \pi}{\omega}\right)-\right. \\
& \left.\left.\tan ^{-1} \frac{\zeta}{\sqrt{11 \zeta^{2}}} \cdot \frac{1+\lambda^{2}}{1-\lambda^{2}}\right\}\right) \ldots \cdots \cdots \cdots(4)
\end{aligned}
$$

また, たて糸長の変量 $x_{0}$ あテンション ローラーの変 位 $x$ と同様に, 開口運動による変量のみとして取扱うと

$$
x_{0}=\frac{B}{2 k}(-1+\cos \omega t)
$$

ただし，

$\omega:$ 強制円振動数

$\omega_{0}$ : 固有円振動数

$\zeta:$ 減衰係数比

$\lambda=\omega / \omega_{0}, \quad \delta=\tan ^{-1} \frac{2 \zeta \lambda}{1-\lambda^{2}}, \quad q=\omega_{0} \sqrt{1-\zeta^{2}}$

\section{2 解析式の検討}

解析式が実際に利用しうるかどうかを検剖するため, 第 1 困に示したような張力们与機構を有する積極送出装 置を取付けた綿用自動緎機およびウォータージェット

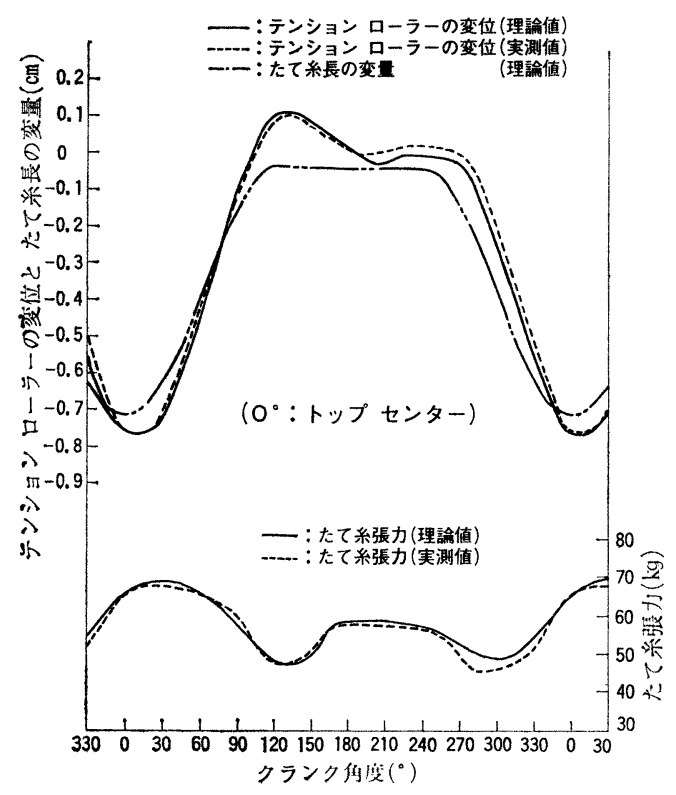

（第 3 图）全常運轵時のテンションローラ 一の変位とたて系厓の変雌扰よ びたて糸张力（線用白動織機）

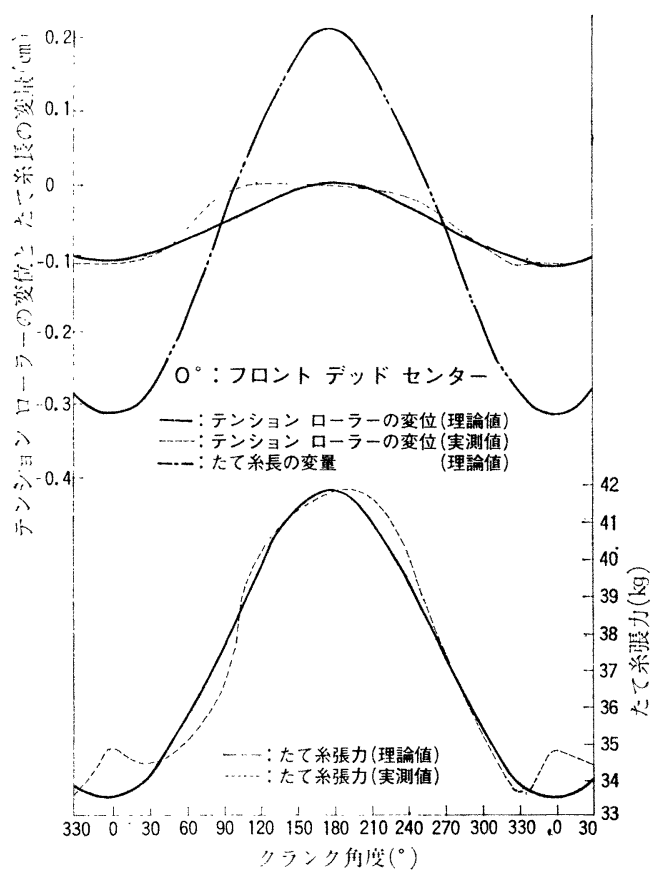

（第 4 図）定常運転時のテンションローラーの 変位とたて系長の変量およびたて系 張力 (ウォータージェットルーム) 
ルームについて, 解析式の一般解よりテンションロー ラーの変位ならびにたて系張力の数值計算を行なった. そして同条件下の実測值とともにてれらの織機について 第 3 図および第 4 図にそれぞれ示した. 第 3 図ではた て糸張力曲線およびテンションローラーの変位曲線の 理論值は実測值とほぼ一致しており, 本解析式が実際の 現象をよく表わしていることがわかる.

第 4 図のたて糸張力曲線について見ると, フロント デッドセンター付近において，実測值に理論值にはみ られないピークが発生している。てれは一種のバンピン グ現象であるが, ウォータージェットルームの場合は 薄織物であってて，製織直後の布は寸分にぬれており， おさ打ちされる布の質量が相当大きくなっているため発 生したものと考えら机る.

しかし, 実測值と理論值との差はわずかに $3.5 \%$ 程度 なので薄織物に関してはとくに問題にする必要はないと 考える。

\section{3. 機械段に関する研究}

ここでは織機の装置の性能面から機械段の実態を把握 し，機械の立場からこれを解消する手段を見山す目的で 行なった基礎的な二，三の研究について述へる。

はじめに，機械段の発生を支配するたて系張ノい变 化に直接影響を及ぼすいくつかの因子について，前節で 導いた理論式を適用するとともに奏測を行ない機械段の 性格を定量的に把握した。

つぎに機械段の実体を実験的に把握するため人為的に 機械段を発生させることができる送出装置を製作して, 不適量送出し之機械段との関係を確かめた。 とくに送川 装置のうち一般に下回りの装置として呼ばれる直接たて 系の送出しを司るビーム駆動機構の部分についての送出 し現象に検討を加えた。さらに送出装置のうち上回りの 装置として重要な役割を演じている張力付与機構におい て, 機械段に関係の深いテンションローラーと張力付 与ばねの両者に対し，そ机ぞれその性能が機械段に及ぼ す影響を実験的に検討した。

\section{「3.1 機械段に対する送出し装置の諸定数の影響}

定常運転中に発生する機械段への影響因子としては, 各クランクサイクルに拈ける送出量, 巻取量が たて糸 張力に占める割合はわずかである.

そこでたて糸張力の変化に直接影響する囚子として テンションローラー等価質量 $m$, ばね定数 $k$ および減 衰係数
係を理論と実測によって定量的に把握するとととした。

まず前節で求めた解析式を $m$ および $k$ の関数で表わ し, それぞれの増減によるたで糸張力の増減を理論的 に解析した。またらについては強制振動における振幅比 の図表より，反の増減によるたて糸張力の増減を把握 した.

前述の綿用自動織機およびウォータージェットルー ムについててれら諸定数を変化させてたて糸張力を測 定した実測值を, 解析式より新たに計算した理論值とと あに第 5 図〜第 7 図に示した:

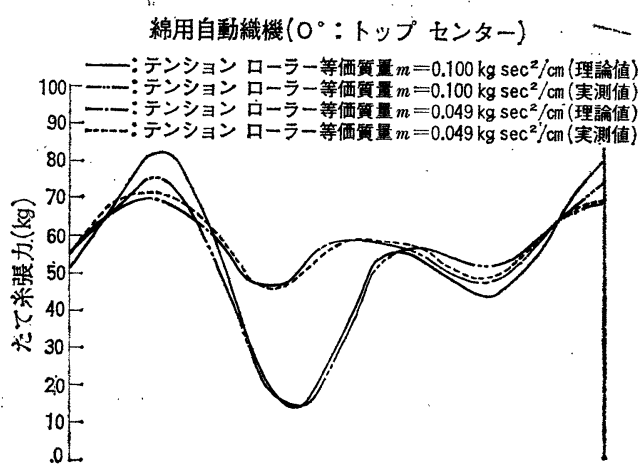

ウォータージェッドルーム(

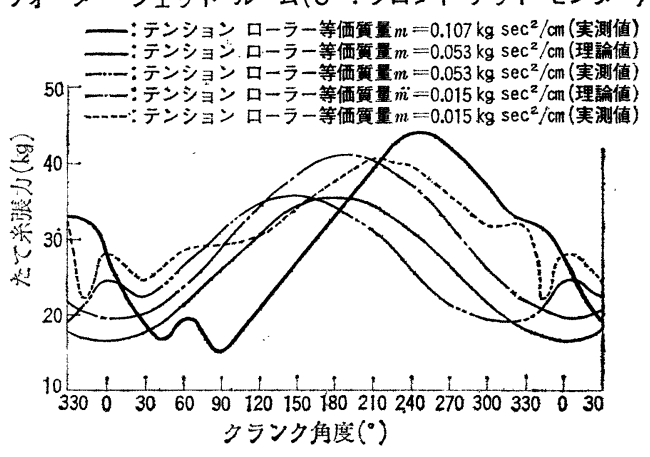

（第 5 図）テンションローラー等価質量が 異なるをきのたて系張力

理論上および各図よりつぎのととがいえる。たたて系張 力の变動幅を減少させるためには, 綿用自動織機に対し ては $m$ を小さくし，ウォータージェットルーム、対 しては位相差が大きくならない籁因内で $m$ を大きな ベきである.

つぎにばね定数・kについては，綿肘白動織機では合 成ば权定数の大きい方がまたウォータージェットル 一ムではそれが小さい方がたて系張力の変動幅は小さ ().

また減衰係数比 $\zeta に$ 関しては，たて系張力の変動幅 を減少させるには綿用自動織機においては とる力がよく，ウォータージェットルームにおいては 


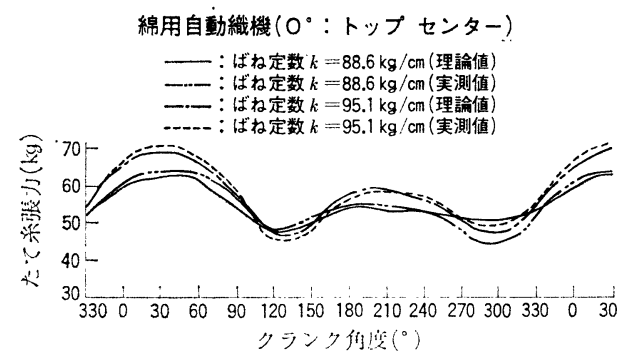

ウォฺータージェットルーム( $0^{\circ}:$ フロント デッド センター)

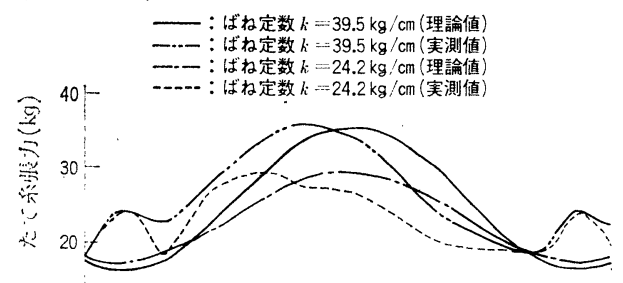

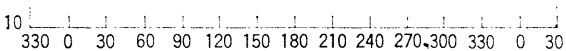
クランク何度 $\left({ }^{\circ}\right)$

（第 6 図）ばね定数 $k$ が買なるときのたて系張力

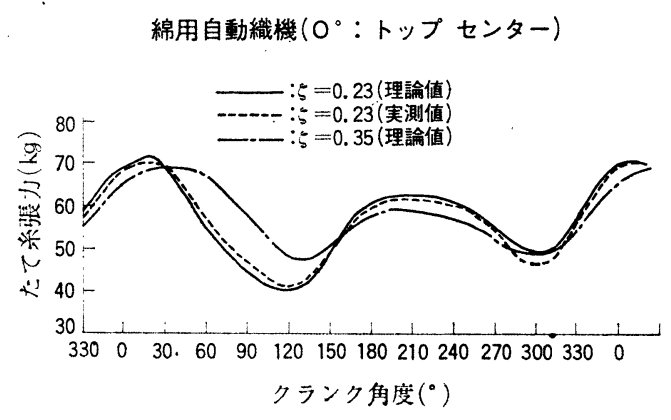

（第 7 区） $\zeta$ が巽なるときのたて系張力

こ机が小さい方がよい。

\section{2 不適量送出しと機械段との関係}

布を製織する場合，布となって巻取られていくたて 系の長さと等量の たて系を送出すように一越ごとにた て糸ビームを厳密に回転させることができれば，送出し 装置に関係する機械段はほとんど問題にされないであろ う. しかし実際問題としては, 温湿度变化による系の伸 䊒，あるいは装虽，部品の慣性や摩擦などの影響によっ て常時適量の送出量を維持することは不可能である.し たがってどのような方式の積極送出装置においても, 送 出量の過不足を補償する制御機構が取入れられており, このような欠陷を補なっている。

そてで過不足のある送出しについて段発生の限界およ び段の規模を知るため，段発生の要因之なる不適量送出
しと機械段との関連を実験的に調べた。

実験方法としては，まず間欠的に過㮃送出しができる ように改造した従来の織機の送出装置を用い，このとき のたて系張力の変動の測定および機械段の発生状況の 把握をそれぞれ同時に行なった. この結果よりたて系 の張力の変動のなかであ織段に直接関係すると考えられ るのは，1サイクル中の変動ではなく，1 サイクルごと の最高張力の変動 (以下張力変動之呼ぶ) であり, 長時 閒記録に打いてその張力曲線の水平直進性が問題である といえる. 張力曲線の波状のピッチは薄段の発生のピッ チとほぼ一致しており, 波の高さすなわち張力変動が大 きいほど薄段が鮮明に現われ, またその波長が長いほど 薄段の幅が広くなっている.

\section{3 テンション ローラーの追従性の影響}

積極送出装置において, たて系張力を直接支配してい るのは, テンションローラーに力を及ぼしているウェ イトあるいはスプリングである. 製織中, ウェイトの自 重あるいはスプリングの抗力が円滑にたて系に働かな ければ張力むらが発生し，てのために機械段を生じさせ る.

テンションローラーにかかっている たて系は開口, 卷取り，送出しならびに おさ打ちなどによって常に移 動するが，その都度テンション ローラーには外力が働 く. 乙の場合, 外力の発生要因の変化住対するテンショ ン ローラーの変化のしかたが張力変動の要点となる.

そこで, 張力付与装置としては, 慣性を小さくするて とと, ジョイントの数を少なくするととが, 張力の復元 時間をはやめ, かつ復元率を高めるのに効果があるとい える.

\section{4 張力付与ばね が織布品質に及ぼす影響}

張力付与源にコイルばねを使用する場合, 特性の異な るばねです静的には同値のたて糸張力を付与すること ができる，そこで実際製織した場合，そのばねの性質 が動的には布面にどのように影響するかを調べた。

その結果ばねの選定にあたっては, 高張力が得られて しかあ変位に対して強さの変わりにくいものが望ましい といえる.したがって ばね定数の小さい ばね㸚して 初期たわみを大きく，すなわち初期張力を高くして用い るのが, 張力付与用ばねとしては有効であった.

\section{4. 止め段に関する研究}

いままで止め段に関して織機の動的特性に起因する起 動停止時のたて系張力の变化の根源に対する追求およ 
びこ机と止め段との関連に対する明確な解析はなされて おらず，またたて系張力以外の止め段の成因に対する 解析もおろそかにされている.

そこで筆者は織機の運動および構造に起因する止め段 の成因を理論的に解析し, 同時に実験を行ない, 乙の理 論を裏付けることによって，乙れらの解析結果を普遍的 なあのと認めようとした。

一方，止め段規模を定量的に把握する目的で，止め段 規模とそれに対応する たて系張力の動的変化の状態と の相関性を実験によって求めた。ここで止め段規模とは よこ系のピッチをいう。したがって薄段はよて系のピ ッチが定常運転時のそ机に比し大きい場合であり，その 逆の場合は厚段となる。

これらの実験にあたり，よて糸のピッチの測定には日 本光学製万能投影機を用いた.

\section{1 止め段の成因}

織機の運動および構造面から見て下記の 3 項目に分け て理論と実験によって解析した。

（1）織機の起動および停止時の回転速度が定常運転 時のそれとは異なるために発生するたて系張 力の変化によるクロスフェルの移動

（2）（1）上同様に回転速度が異なるためにレース に発生するたわみが異なり，そのための打込 まれるよこ系の位置の定常時からのずれ

（3）織機の停止中におけるたて系張力の弛緩によ るクロスフェルの移動

\section{2 たて糸張力の動的変化}

たて系張力の変化は, 織機の起動およご停止時の回転 速度が定常時のそれ之異なるために発生するあのと仮定 し，その仮定に基づいて解析を進めた。 停止している織 機を起動したり，または定常運転中の織機を停止したり する場合，定常状態に至る時間および停止するまでに荘 する過渡状態の時間は，織機回転数やブレーキ装置およ びモーターの特性その他種々の条件によってそれぞれ異 なるが，この起動抢よび停止状態を測定し，クランク角 度を時間の関数として表わし，てれよりえられた解速度 および強制振動数を解析式に代入し，数值計算を行な い，同条件下の実測值とともに第 8 図〜第 11 図に示し た.

図に示される起動および停止時におけるおさ打ち前 後のたて系張力変化により，クロスフェルが移動して 止め段を生成していると考えてよい。

この張力変化量より数值計算したクロスフェルの移動

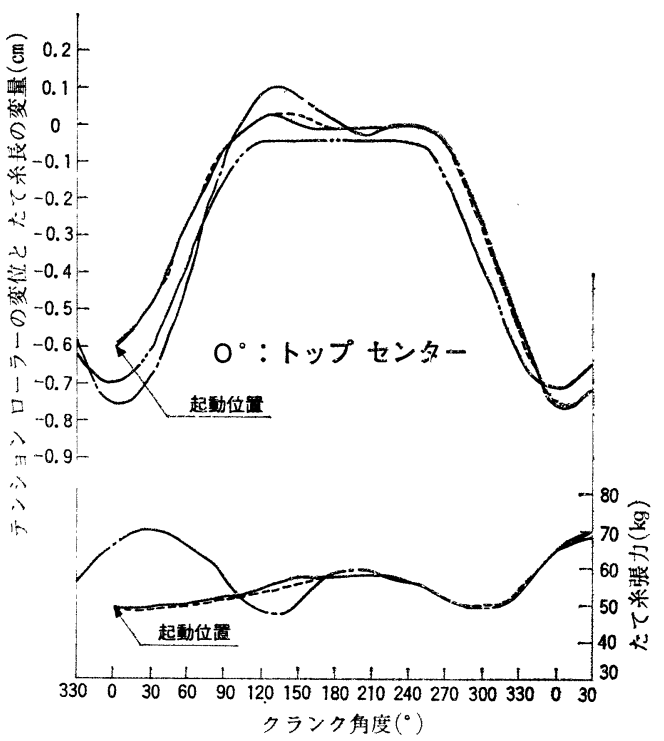

-ーー: 定常時のテンション ローラーの変位および たて系張力(理論値) ——:起動時のテンション ローラーの変位およびたて糸張力(理确俌)

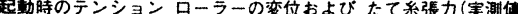

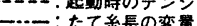

（笴 8 図）起動㭙におけるテンションローラ 一の変位とたて系医の変暗拈よじ たて乐张力（綿用自動織機）

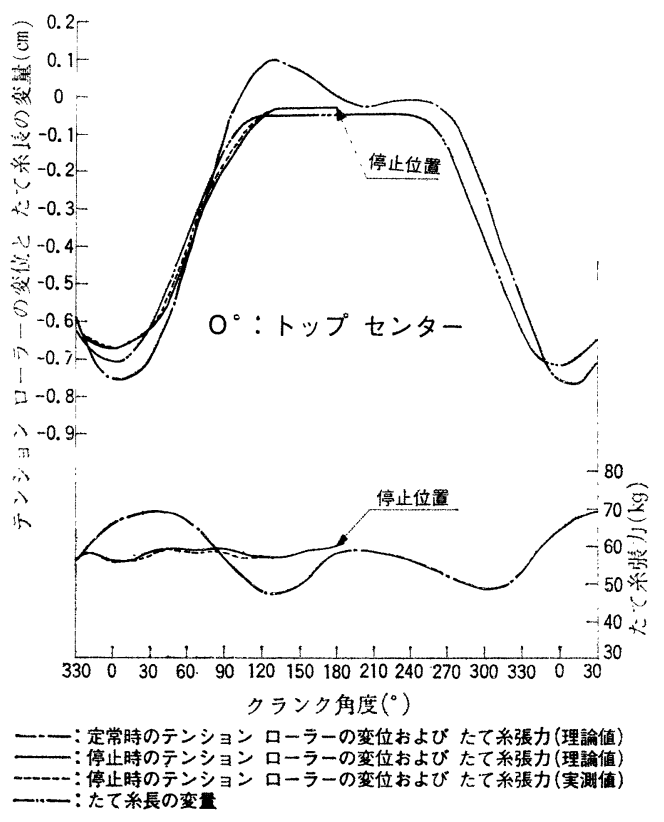

（第 9 図）停止時におけるテンションローラ 一の変位とたて系長の変量および たて糸張力（綿用自動織機）

量が，止段規模に及ぼす影響は綿用自動織機では約 90 \%でありウォータージェットルームでは約 $13 \%$ 程 度であることを確認した。 


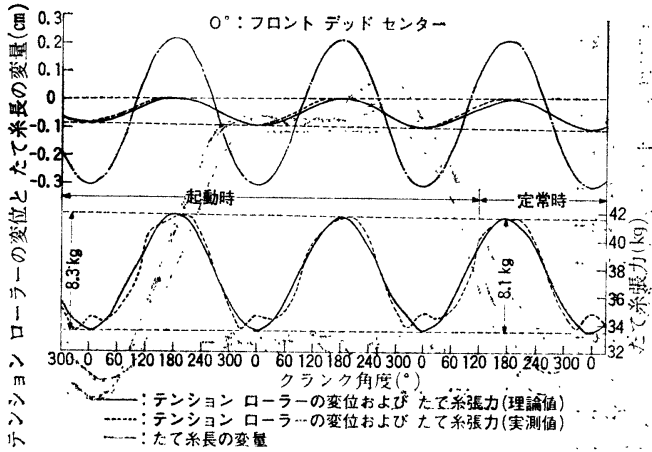

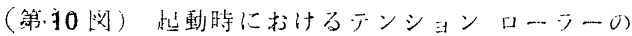

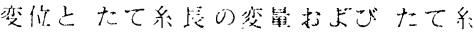

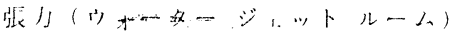

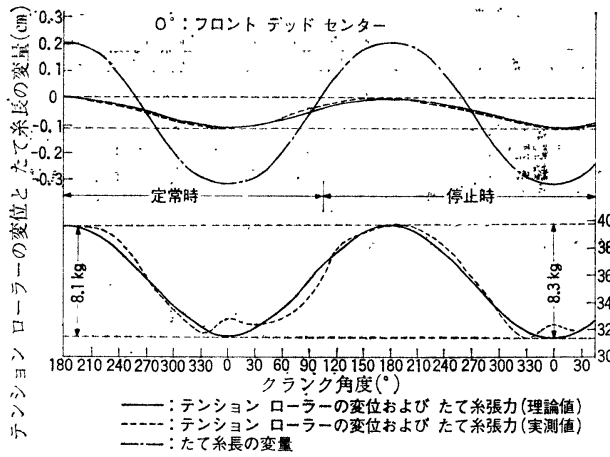

（第11図）停止時に抬けるテンションローラーの 变位とたて系铰の変量打よびたて系 張力 (ウォータージェットルーム)

\section{3 レースの たわみ量}

レースは衏回前後運動しているため，自身の壁舅によ ってレースソードとの結命部存支点としてたわ子が発 隹する.しかし, 起動および停止時には, その扣速度が 定常運転時と異なるために，上くにおさ打ち時すなわ ちプントデッドセツター付近ではそのたわみ量が 異なった值を示す。こ机は当然上こ糸のおかれる位型 に影響し，止段発件の原因の一つとなっている。ウ办

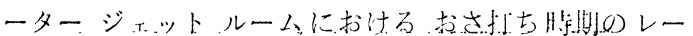

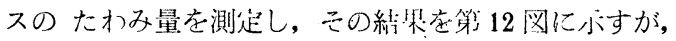

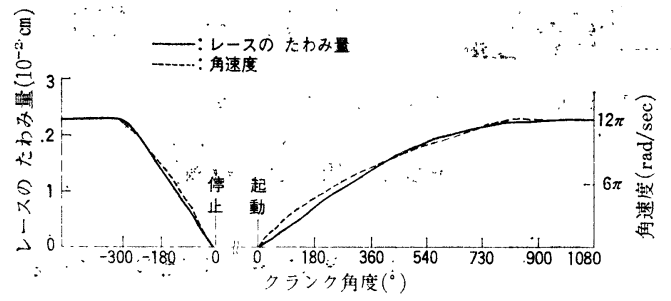

（符12四）おさ打時のレースのたわみ量と角速度 比較図（ウォータージェットルーム）
こ扎よりレースのたわみ蝫はクラシク打速度の関数上 みなしてよい.

レースのたわみがリードのたわみ影響ずることは

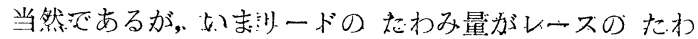

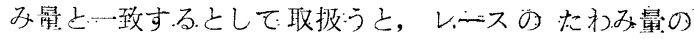

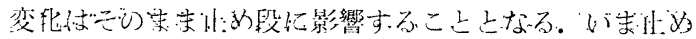

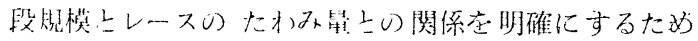

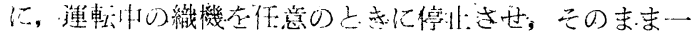

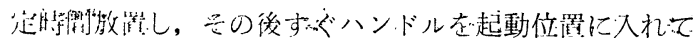

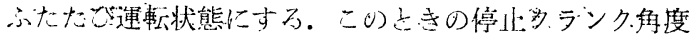

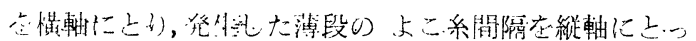

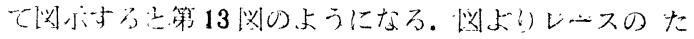

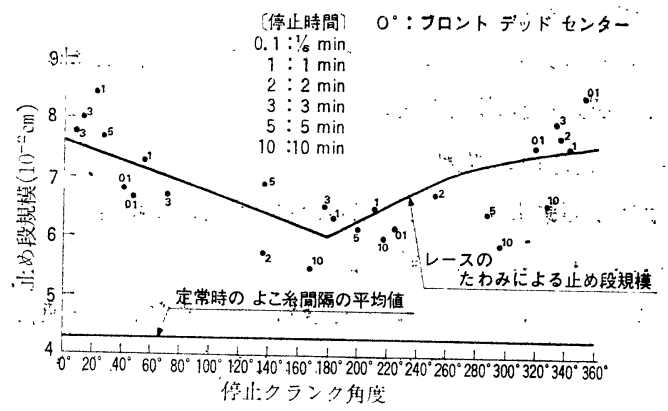

（第 13 図）停止クランク角度のまま一定時閒放圆した のち起動（ウォータージェットルーム）

わみ量の変化が止め段規模に占める割命は大きいことが うかがえる。

\section{4 たて糸張力の弛緩}

第 14 四，第15図に示されるように，停止後のたて系 張执どのようなクランク位置で浐小:しても約 $2 \mathrm{~min}$

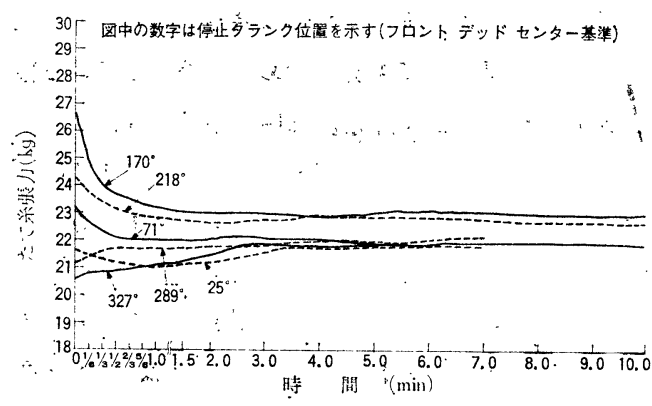

（符 14図）織機停止巾のたて系張力変化 (ウォータージ_...ト ルーム) (俈州:のまま放湤)

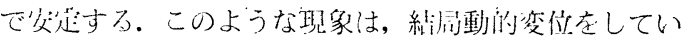
るテンションローラーおよびたて系などが急に停止 し, 動摩擦の平衡状態加ら静摩擦のそ机一比較的早く移 るととを意味している.しかす止め段規模は $2 \mathrm{~min}$ か 


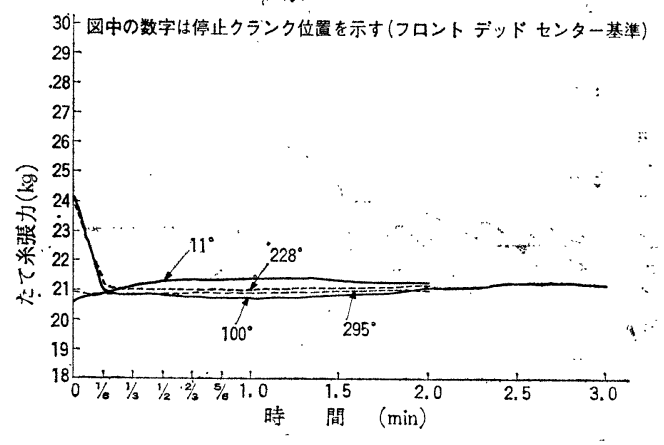

（第 15 図）停止後のたて系張力変化

(ウォータージェットルーム)

(停止後すぐこうこう一政にして放置)

ら $10 \mathrm{~min}$ という大きな停止時閒にもかかわらずこの変 化が少ないことから，たで系張力の池緩が止め段規模に 占める割合は非嫦に少ないと考えられる。

\section{5 止め段規模の傾向}

止め段は織機が停止するととによって発生するが，こ の規模は, 織機の回転数, テンションローラー系の慣 性モーメントおよび そうこう一致時期などによっても 異なる。

そこでこれらのいくつかの組合わせに刘するたて系 張力の測定結果第 $16 〜 18$ 図に，またそ机らに刘応す る止め段規模の測定結果の一例在第 $19 \sim 21$ 図に示す.

$$
\text { O゚:トップセンター }
$$
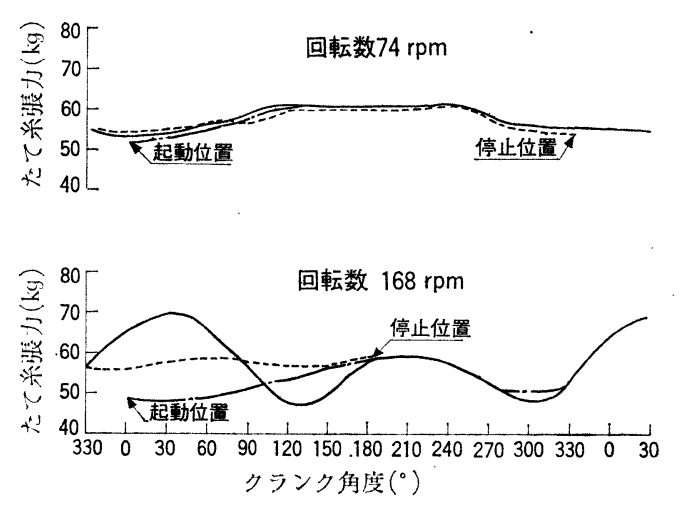

（符 16 図）回転数が翼なるときのたて糸張力 (綿用自動織機)

こ机らの図からわかるように止め段規模を小さくする には線用自動織機においては, テンションローラー系 の慣性モーメントを小さくし，ウォータージェットル ームに扔いては, テンション スプリングの ばね定数を
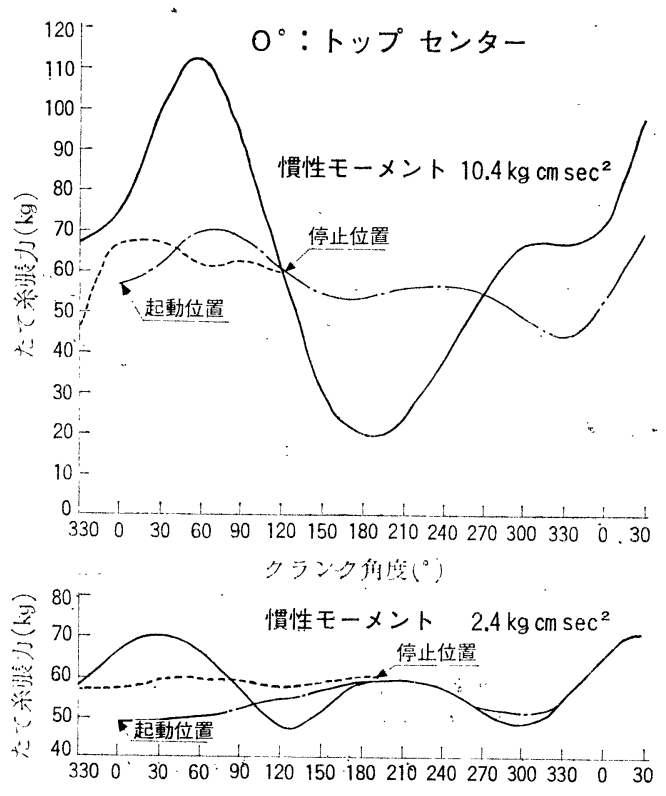
クシンク任度 $\left({ }^{\circ}\right)$

$$
\text { - : 定常時 - - : 起動時 -..- : 停止時 }
$$

（第 17 図）慣性モーメントが異なるときの たて系張力（綿用自動織機）
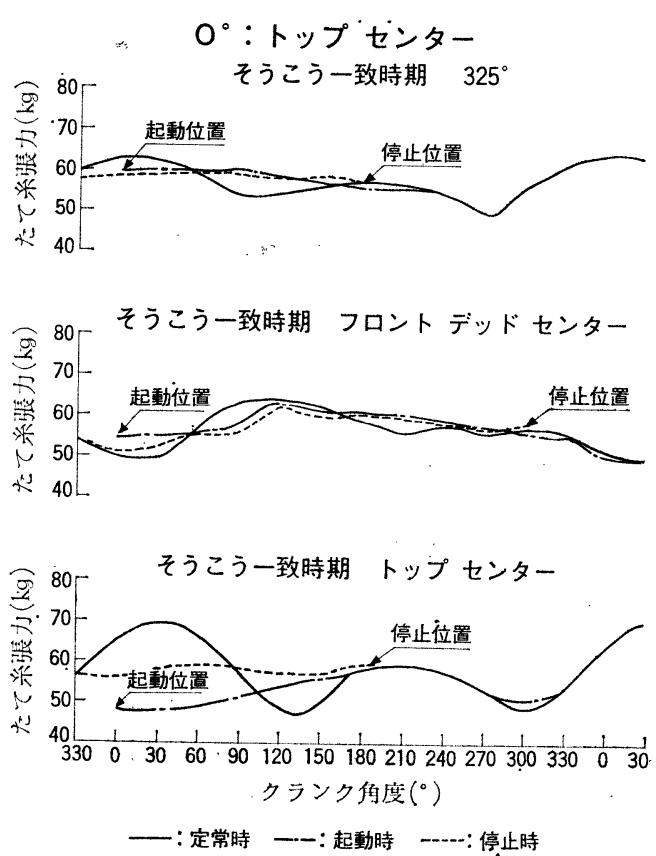

（第18図）そうこう一致時期が買なるときの たて系張力（綿用自動織機）

小さくすればよい，しかし，クランクの体速度 $\omega$ の変化 が上如段規模に占める割合の大きいととが明らかにされ

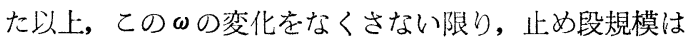
小さくすることはできてあ解消することはできない。 $\omega$ 


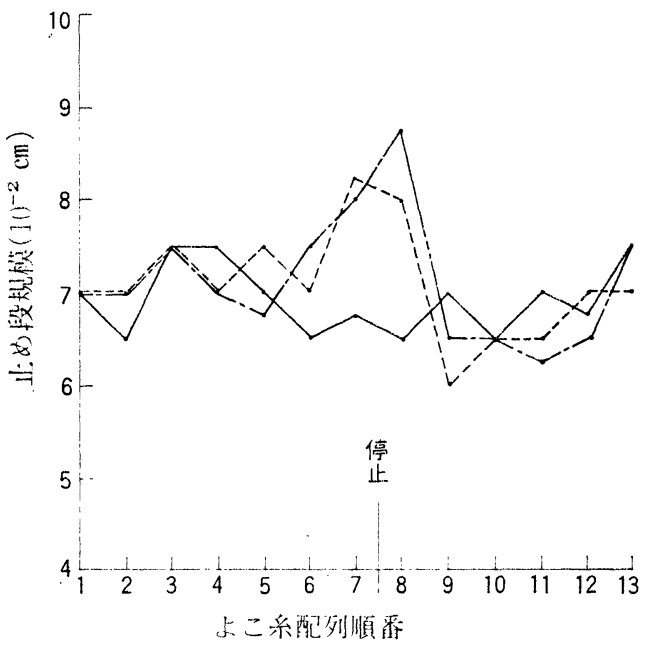

- : 回転数 $70 \mathrm{rpm}$ : 回転数 $210 \mathrm{rpm}$

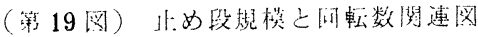
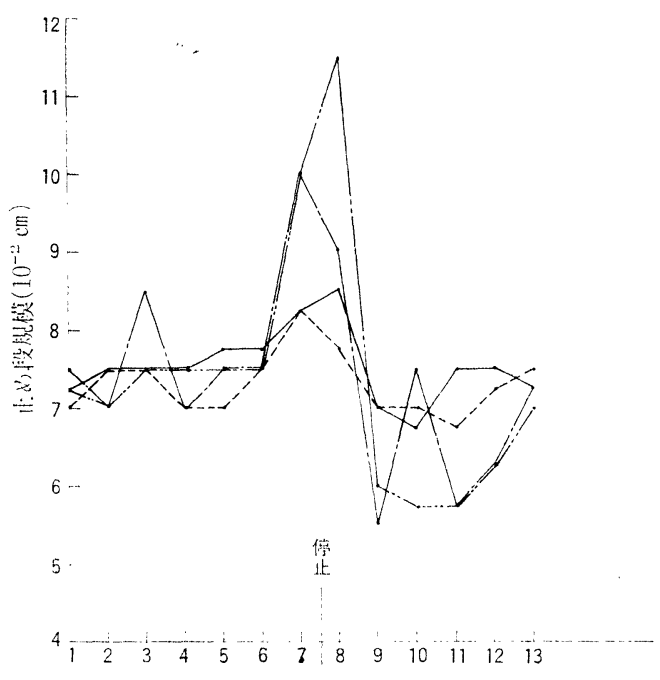
卡二产配列脽醉

‥-- : 憎性モーメント $1.5 \mathrm{~kg} \mathrm{~cm} \mathrm{sec}{ }^{2}$ 一: 惯性モーメント $2.4 \mathrm{~kg} \mathrm{~cm} \mathrm{sec}$ …: 慣性モーメント $10.4 \mathrm{~kg} \mathrm{~cm} \mathrm{sec} \mathrm{sec}^{2}$ - - : 慣性モーメント $16.1 \mathrm{~kg} \mathrm{~cm} \mathrm{sec}{ }^{2}$

（第 20 図）边: 段規模之慣性モーメント 関連图(綿用白動織機)

の変化に影響されるものは，起動および停止时のたて 系張力の变動ならでにレースのたわみ量である。綿朋 自動織機ではたて糸張力の变動が主上して止め段規模 を支配し，ウォータージェットルームではレースの たわみ量が主として支配する。しかし，レースのたわ み量はレースの補強などにより小さくしうるのだ, その 場合にはウォータージェットルームにおいても，たて 系張力の変動が止如段規模に上占割合が大きくなる上 考えら机る。しかし一百, ウォータージェットルーム においてはレース系の慣性モーメントを大きくすると起

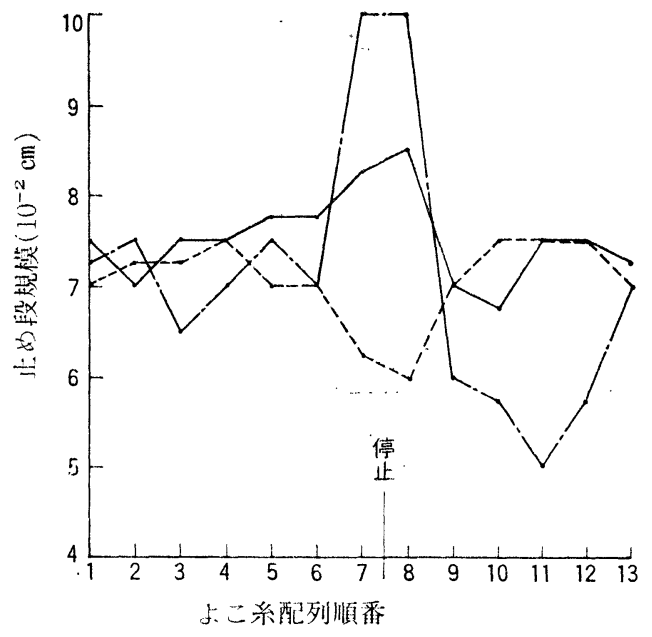

- : そうこう一致時間 トップセンター

--ー：そうこう一致時間 フロント デッドセンター ---：そうこう一致時間 $325^{\circ}$

(第 21 図) 止め段規模とそうこう一致時 期関連図(綿用自動織機)

動および停止時の $\omega$ の変化が小さくなり，よこ系閻隔の 変化がゆるやかになり，見かけ上極端な薄段が現われな い. このようにゆるやかに起動および停止することは, 従来の有ひ織機では ひ投げ方法の性格上不可能であっ て，新しいよこ入れ方式を有するいわゆる䪊織機の 特性としてまことに興味深い.

此段を解消する最普の手段はのの变化をなくすこと であるが，乙礼を完全になくすことは，モーターの特

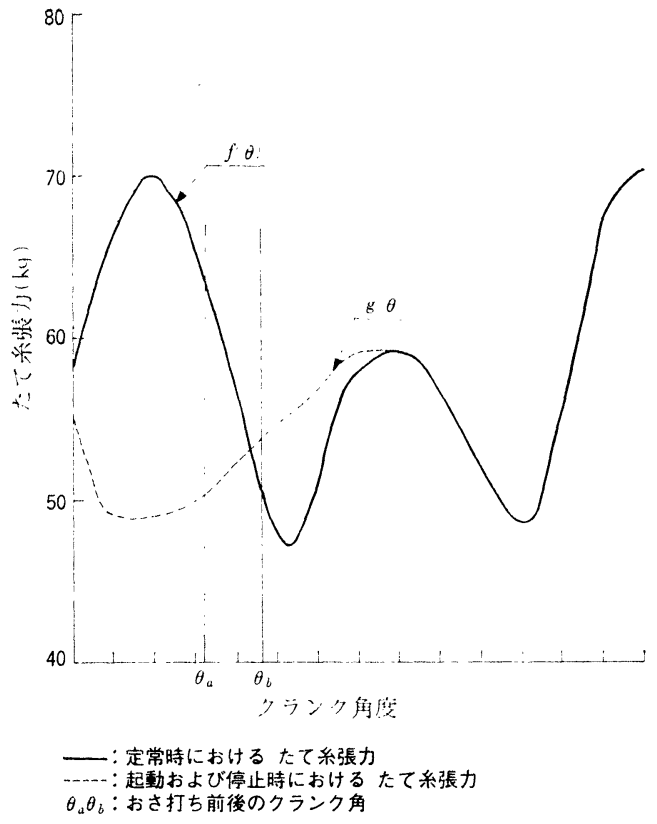

（第 22 図）たて糸張力曲線（綿用自動織機） 
性, 織機の慣性なごから考えて不可能である，換言すれ ば起動および停止時のたて糸張力をクランク角度全区 間にわたって定常運転時と一致させること㹥不可能であ る.そこでたて糸張力の変動による止め段を防止する 方法として, 起動および停止時のおさ打ち前後のたて 系張力だけでも定常運転時のそれと平均值的に一致する よう補正することが考えられる。

すなおち第 22 図および第 23 図において

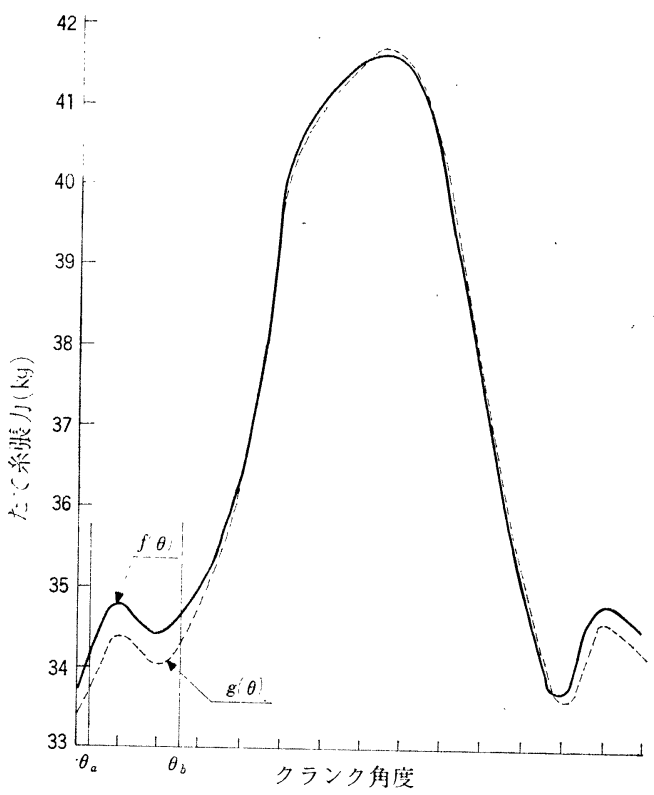

一: 定常時におけるたて糸張力

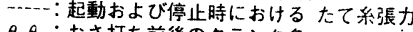

$\theta_{a} \theta_{b}:$ おさ打ち前後のクランク角

（第 23 図）たて系張力曲線

(ウォータージェットルーム)

$$
\int_{\theta a}^{\theta_{b}} f(\theta) d \theta=\int_{\theta a}^{\theta_{b}} g(\theta) d \theta
$$

が成立つようにすればよい。

ここで

$f(\theta)$ : 定常時におけるたて糸張力曲線

$g(\theta)$ : 起動および停止時におけるたて糸張力曲線

$\theta a, \theta_{b}:$ おさ打萠後のクランク角

この考えにそって開発した止め段防止装置およびその 効果については次節で詳述する.

\section{5. 織段防止装置の開発}

前節までの解析や実験結果に基づいて, 織段を解消す る具体的装置の開発に対する研究結果について述へる.

機械段に対しては,たて系張力付与装置の良否が織段 の発生に大きく影響することから，たて系の経路，張力 付与ばねの形態およびテンションローラーの迎彷性に
ついて検討し, 操作面をも考慮に入れた簡単な構造で織 段を防止できる簡易形積極送出装置存開発した。

止め段に対しては，モータ一の起動特性抢よで織機の 慣性などから，たて系張力在起動およご停止時と定常運 転時との全区開にわたって一致させるような具体的な力 策を講ずることは非常にむずかしいと考え，起動および 停止時に対しておさ打ち以前のあるグランク解度閐に

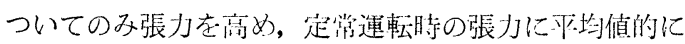
一致させるとととした。すなおち，テンションローラ 一にイージング運動を兼权させている張力付与装置にお いては，開口運動が そうこう一致から最大開口に進行 するときつまりテンションローラーが織前に引需せ られるときに，テンションローラーの運動を拘束する と，ひロが開くにつ机てたて糸張力が増加する。 また 逆に最大開口からそうこう一致に進行するときにテン ション゙ローラーの運動を拘束すると，ひ口が閘じるに つれてたて系張力が減少するととになる.

このような現象を利用して，そうこう一致がトップ センターである場合は, トップセンターからおさ打ち までのある区聞テンションローラーの運動を拘束すれ ば，おさ打ち以前のたて系張力店高めることができ 万.

またそうこう一致がフロント デッドセンターであ る場合は，おさ打ち直前のひ口は次第に閉じつつあるか ら,この区简でテンションローラーの連動老拘束する

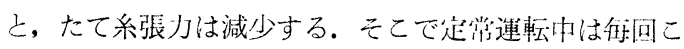
のような拘束を行ない, 張力を高めたい上きだけ拘束し ないようにすれば，夹質的にはこのときだけ張力を堌加 させたことになる。

したがって紡績系の織成に多用されているトップセ ンターでのそうこう一致の場合については前者を, ま たフィラメント糸の織成に多用されているフロントデ ッドセンターでのそうこう一致の場合に対しては後者 を採用すれば, おさ打ち以前のあるクランク角度間のた て系張力を定常時の張力之平均值的に一致させることが 可能である。

またテンション ローラーとは別個にイージングロー ラーを具備している方式のものであれば，テンション ローラーはイージング運動を行なわないため, 上述の方 法ではおさ打ち直前の張力を高める效果はない，乙の 方式のものでは正規のイージング ローラーの喗動に刘 して強制的に变化を与えることによって，その时期だけ 局部的にたて系張力を增減することができる。 
ラこの原理を起動および停止時に利用してたて系張力 を定常運転時之平均値的䎲一致させることができる。

て本断ら手段を具体化し，一般に用いられている織機 の送出装置に簡単に取入机ることのできる第 24 図およ゙ び第25図に示すような止め段防止装置を開発した。

\section{ブレーキ カム(4)のプロフィル}
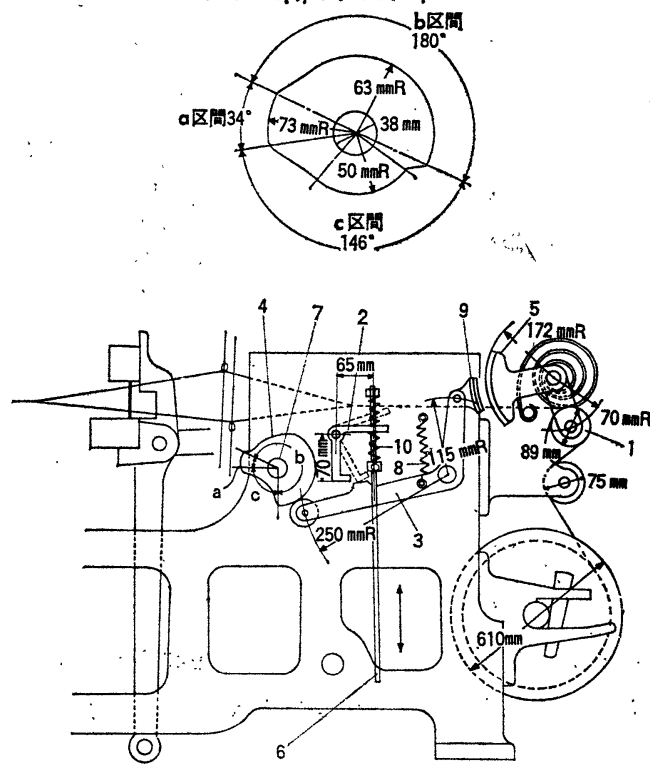

（第 24 図）拘束型止め段防止装置

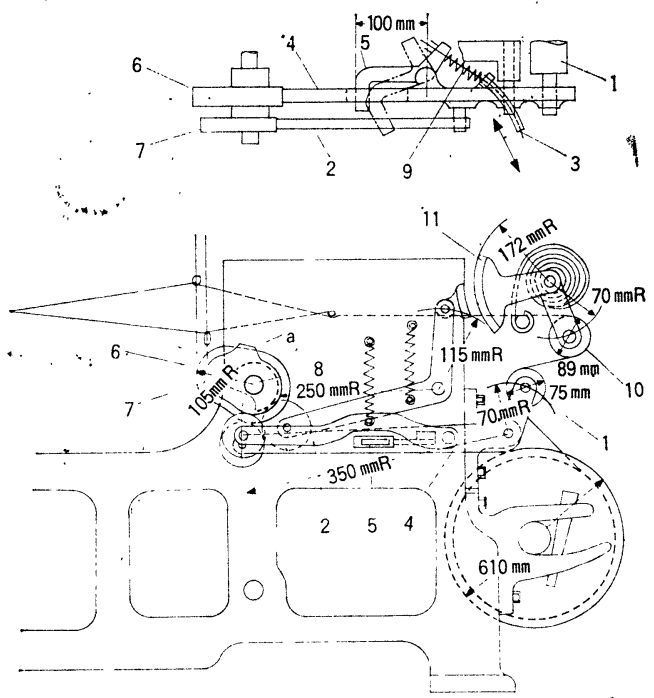

（第 25 図）強制型止め段防止装置

この止め段防止装置を組込んだ簡易形樍極送计装置を 綿用自動織機に取付け，製織実験を行なったところ止め 段の発生はまったくなく, この装置のすぐれているとと が確かめられた。
しかし,ウォータージェットルームについては, 止 め段規模はレースのたわみ量の差によるものが大半を 占めることが判明した。これに対してはレースを補強す。 るととすに人為的なペダル操作にようて起動直前にた て系張力を増加させるよこ系間隔補正装置を採用するる ことにより如段を小さくすることができた。なお綿扴

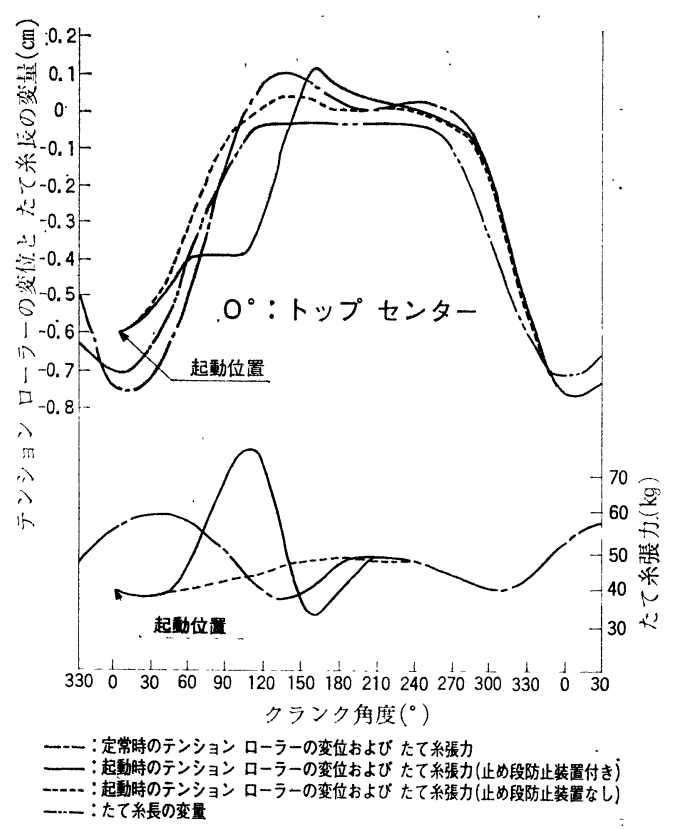

（第 26 図）起動時におけるテンションローラーの変位 とたて系長の変量およびたを系張力曲線

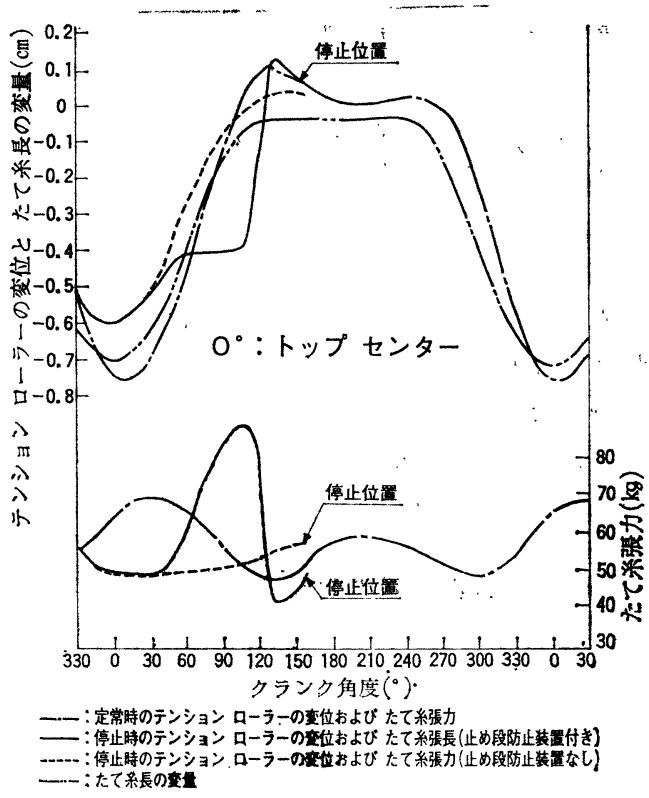

（第 27 図）停此時におけるテンションローラーの変 位とたて糸長の変量およびたて系張力 
白動織機に扔いで且め段防止装置の有無による起動およ び停正時のたて系張力曲線ならごに止め段の規模をそ れぞれ第 26 図＼cjkstart第 28 图に示した。

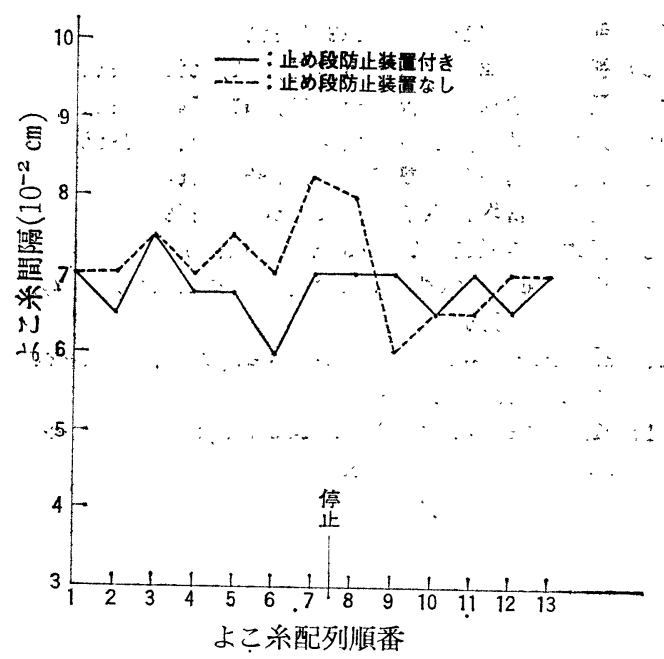

（第 28 図）止め段規模之止め段防止装置の関連図

\section{6. むすび}

張力付与系とたて系張力との動的な関係を解析し, てれが織段に及ぼす影響を䒠駼们にしらべた結果，つぎ のことがらが明らかになった。

まず機械段に対しては

(1) クランク1サイクルごとの最高張力の変動が機械 段を発生させ，その張力変動の大きさとピッチとが段の 鮮明度とピッチとに正の相関関係を有する

（2）綿用自動織機で 回転数が $200 \mathrm{rpm}$ 以下の低速運 転の場合には, 張力付与系の慣性モーメントよりもその 系の軸䅇擦の方が機械段に及ぼす影響が大きい

（3）ばねを張力付与源上する場合は，ばね起数の小さ いナが機械段は発生しにくい

また止わ段に関しては

（1）定常運転時に対し，起動および停止時における おさ打ち以前のたて系張力が低いほど止め段は湿著で ある

（2）乙の現象は回転数が大きい場合には，テンション ローラー系の慣性:モーメントが大きい場合および そう こう一致時期がトップ センターよりフロント デッド センターに近い場合の方が顕著になり，止好段がはっき り現われる

（3）おさ打ち以後つぎのおさ打ちまでの閏における たて系張力の定常運転時に刘する差異が止め段に及ぼす
影響は少ない

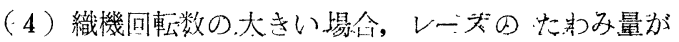

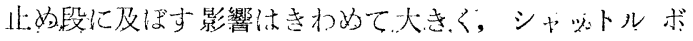

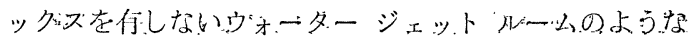
織機の場合㹥これ为止好段规模を支配しでいる

(5). ウォーター・ジェットルームだけでない，シャ就 トル織機のようなピッキング機構を有しないい枕る革 新織機において，止好段を防止する便汒として，ゆるや かに起動を行なうのが有効なととがわかった

（6）止段在防止する炕は起動扰上び停止㭙のおさ 打与前後のたて系張力を定常運転时すそ机と平均值的 に一致させるとよい

つぎに理論的な解析からはつぎのことがらが明らかに なった.

（1）クランク1サイクル中のたて系張力の変動に最 屯大きく影響するのは, 綿用自動織機ではテンション ローラー系の慣性質量であり, ウォータージェットル 一ムでは行とたて系上テンションス ブリングの合成ば ね定数である.したがって製織中のたて系張力変動を 小さくするには，綿用自動織機ではテンションローラ 一系の慣性質量を小さくするのが良く, ウォータージ ェットルームでは張力付与のば称定数索小さくするこ と，たて系絸路を長くすることが良い

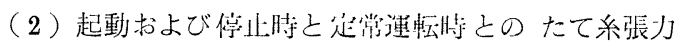
の差は織機の回転速度のちがいに起因するところが大き い

（3）起動および停止時の たて糸張力の変動が止め段 規模に及ぼす度合は, 綿用自動織機では非常に大きく, ウォータージェットルームではわずかである

以上の結果を綜合して機械段执よび止好段を防止する

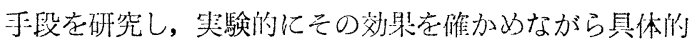
な織段防止装置を開発した。

すなわち, 機械段に対してはたて系の経路, 張力付 与ばねの形態およびテンションローラーの追従性に刘 して検討し, 実用性のある織段防止構造を有する装置を 試作した.

また止め段に対しては起動および停止時におけるお さ打ち前後のたて糸張力を定常運転時のそれと平均値 的に一致させるのに, テンションローラーの運動の性 格を利用した簡単で実用性のある止ぬ段防止装置を試作 した.

（付記）本研究のうち機械段の解析はランダムに発生す る機栈段のみに片寄った感があり，周期的に発生する機 
44.

械段の解析が不十分であった。

この周期性を帯びた機械段の解明が今後に残された研 究課題であるが, 現在筆者は布面において, この周期成 分を自己相関関数を使用して解明しており, また織機に おいては, 送出装置, 巻取装置, 開口装置などの各装置 における運動部分の周期成分およびフレーム, レール類 などの振動の周期成分をそれぞれ解明している.

\section{参考 分 献}

1). 乾；瀻機論文集, 20, T307（1967）

2) 乾, 倉田; 繊機論文集, 21, T 232（1968）

3 ）乾, 倉田; 緇機論文集, 23, T83（1970）

4) 乾, 倉田; 絨機論文集, 23, T91 (1970)

5 ) A. E. Owen; J. Text. Inst., 19, T365(1928)

6 ) H. Chamberlain, D. C. Snowden; J. Text. Inst., 39, T28 (1948)
緎維工学

7 ) F. Stein; Diss. T. H. Stuttgart (1926)

8 ) F. Stein; Melliand Textilber., 8, 994 (1927)

9) F. Stein; Kunstseide, 10, 121 (1928)

10) H. Keller; Diss. E. T. H. Zürich (1943)

11）三浦, 宇野；緎機誌，5，45（1952）

12）鴨川；䋐機誌，12，629（1959）

13）鴨川, 室津, 泉沢; 織機誌, 13, 555 (1960)

14）鴨川, 室津, 泉沢; 瀻機誌, 13, 747 (1960)

15）久世, 酒井, 三原; 緎学誌, 11,192 (1955)

16）久世, 酒井；瀻機誌, 17, 793（1964）

17）切替, 富塚; 織学誌, 15, 647 (1959)

18）沢木；瀻機誌, 2, No. 6, 7 (1949)

19) K. Greenwood et al; J. Text. Inst., 47, T241 (1956)

20) K. Greenwood, G. N. Vaughar; J. Text. Inst., 48, T39 (1957)

21) K. Greenwood, W. T. Mclaughlin; J. Text. Inst., 56, T314 (1965) 